\title{
Maradó fogazatot érintő balesetet követő komplex rehabilitáció az esztétikai zónában
}

\author{
Esetismertetés
}

DR. MIKLÓS RÉKA, DR. KEMPER RÓBERT

\begin{abstract}
Esetismertetésünk célja, hogy egy általunk követett kezelési útvonalat bemutassunk balesetben sérült fogak helyreállítására. Nehézsége az esetnek, hogy a felső négy frontfog mind érintett volt, így a kezelés időbeni lefolyásának tervezése külön figyelmet érdemelt. A 11, 12 és 22 fogak nem voltak megtarthatók, a 21-es fog rotálódott és elszíneződött a baleset következtében. A helyesen kivitelezett és jól időzített sebészi folyamatokkal célunk az volt, hogy megőrizzük az eredeti nyálkahártyalefutást és papillamagasságokat, ezért az implantátumok behelyezését socket shield technikával kiegészített azonnali implantációval végeztük, két részletben. Az implantátumokon azonnali ideiglenes korona készítése csak a 11-es esetében volt lehetséges, a többi esetben a három hónapos gyógyulási idő leteltével terheltük az implantátumokat. Az ideiglenes koronákat az esztétikus nyálkahártya-lefutásnak megfelelően formáztuk a lenyomatvétel előtt. Az elszíneződött 21-es fogat préskerámia-héjjal borítottuk. A lenyomatot egyéni lenyomati fejes módszerrel vettük. Végeredményben stabil, eredeti állapotában megőrzött lágyszövetet kaptunk, fémmentes eljárással készített implantátumra felcsavarozható esztétikus koronákkal és héjjal, ami igazolta a kezelési tervünk helyes megválasztását.
\end{abstract}

Kulcsszavak: baleset, socket shield technika, azonnali implantáció, egyéni lenyomati fej, fémmentes

\section{Bevezetés}

Az esztétikai zóna sérült fogainak rehabilitációja komplex feladatot jelent a fogorvos számára. Baleset következtében eltört vagy elvesztett maradó fogak esetében pedig a protetikai helyreállítás mellett sokszor sebészi beavatkozásra is szükség van. A modern implantációs irányelvek és a fémmentes protetikai eljárások ötvözése azonban megoldást jelenthet a bonyolultabb helyreállító folyamatok esetén is. A fogakat érintő balesetek előfordulása gyakoribb az aktív életet élők körében, és többnyire a maxilla frontfogai sérülnek. Irodalmi adatok alapján a maradó fogazat sérülése gyakoribb, okozója leggyakrabban sporttevékenység (40\%), biciklibaleset (20\%), közúti baleset $(8 \%)$ vagy erőszak okozta fogsérülés $(6 \%)$. A traumák szakszerű ellátásában az esztétika és a funkció helyreállítása is elengedhetetlen, és ez sokszor elhúzódó, akár életen át tartó kezelést, illetve utókezelést igényelhet. [12]

\section{Az első találkozás}

Páciensünk 43 éves nő, kerékpárbalesetét követően kereste fel rendelőnket. Anamnézisében ismert betegség nem szerepelt, káros szokásai nincsenek, tartósan gyógyszert nem szed, és gyógyszerallergiáról sem tud. Szájhigiéniája megfelelő, elmondása alapján rendszere- sen részt vett évenkénti fogászati ellenőrzésen. A klinikai vizsgálat és a rendelkezésünkre álló $\mathrm{CBCT}$ felvétel elemzése alapján a felső négy metszőfog sérült a balesetben (1. kép). A 11-es fog horizonto-vertikális fraktúrát, a 12-es és a 22-es fogak pedig subgingivalis horizontalis fraktúrát szenvedtek. A 21-es fog a trauma hatására subluxálódott és rotálódott, de vitalitását megtartotta (2. kép). Az arcon és a felső ajakon található bőrsérülések nem befolyásolták kezelésünket.

\section{Kezelési terv}

Elsődleges célunk a fraktúrált fogak [11, 12, 22] eltávolítása és implantátumokkal való pótlása volt. A postextractiós leépülés többnyire a buccalis csontfalat érinti a leginkább, amely a maxilla front régiójában az esztétikum csökkenését eredményezheti [2]. Páciensünknél az érintett foggyökerek úgy rotálódtak, hogy azok megszakították a buccalis csontfal folytonosságát. Ilyen esetben, a foggyökér eltávolítása esetén a baleset miatt már eleve sérült buccalis csontfal kiszámíthatatlan felszívódása várható. [7]. 2010-ben Hürzeler és munkatársai kifejlesztették a socket shield technikát, ami megoldást jelenthet a problémára [6]. Korábbi azonnali implantációs technikákkal összehasonlítva a socket shield technika megőrzi a buccalis köteges csont gyökérhártya felőli vérkeringését, minimálinvazívabb, és jobb 


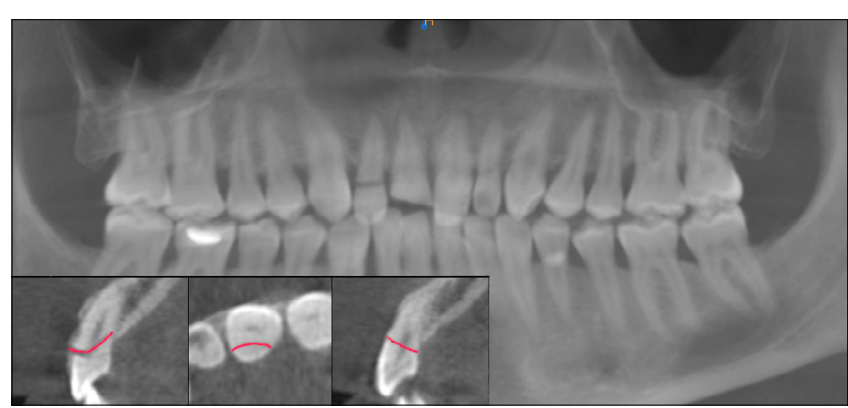

1. kép: Háromdimenziós CBCT-felvétel a balesetet követően, piros vonallal kiemelve a fraktúrák vonalai

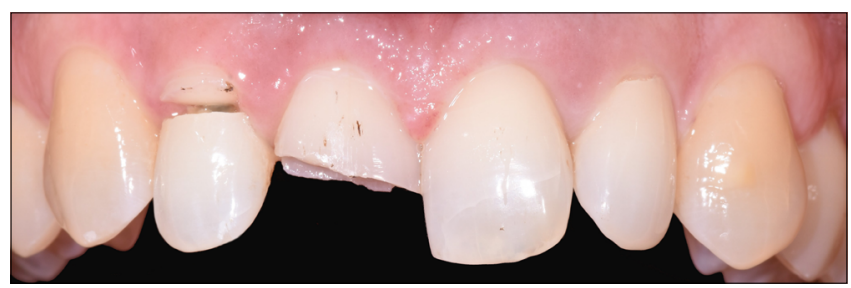

2. kép: A fogazat sérülése, klinikai kép

gyógyulást eredményez. Az eljárás lényege, hogy az eltávolítandó fog sérülésmentes buccalis gyökérrészlete az extractio során megtartásra kerül. Az érintett gyökér csúcsát minden esetben el kell távolítani, ami a ráláthatóság hiánya miatt nehézséget jelenthet. Az implantátumot a gyökérfragmentumtól palatinálisan helyezzük be, a fennmaradó rést pedig saját vagy mesterséges csontpótló anyaggal töltjük ki. Az eljárást alkalmazva a buccalis csontfal kisebb mértékű leépülésére számítunk, ezzel elősegíthetjük az esztétikai zónába eső területek hosszú távon is stabil, esztétikailag is sikeres rehabilitálását $[4,6,13]$. Esetünkben indokoltnak tartottuk az azonnali implantálást socket shield technikával végezni mind a három implantátum behelyezésénél. Ha az implantátumok primer stabilitása eléri az azonnali terhelhetőség határértékét $(32 \mathrm{Ncm})$, ideiglenes implantátumfejen elhorgonyzott kompozit koronát készítünk páciensünknek [1]. Az azonnali felcsavarozható ideiglenes korona számos előnnyel jár az orvos és a páciens számára is: a periimplantaris lágyszövet gyógyulása kedvezőbb kimenetelü, a páciens komfortérzete pedig fokozódik a szomszédos foghoz rögzítendő ideiglenes Maryland-hídhoz képest [10].

A baleset a maxilla csontszerkezetében is sérüléseket, apróbb fraktúrákat is okozhatott - mivel a frontfogak a baleset előtti állapothoz képest más pozícióban helyezkedtek el -, így a tervezett implantátumok behelyezését három hónapos gyógyulási időszak utánra időzítettük. Ezalatt a fogakat devitalizáltuk, ideiglenesen rögzítettük és kompozit anyaggal kiegészítettük. A három implantátumot külön-külön időkben helyezzük be a fogakat övező természetes papilla megőrzése céljából.

A 21-es fogra préskerámia-héj készítését javasoltuk, amivel korrigálni tudjuk a rotációt és a színkülönbséget

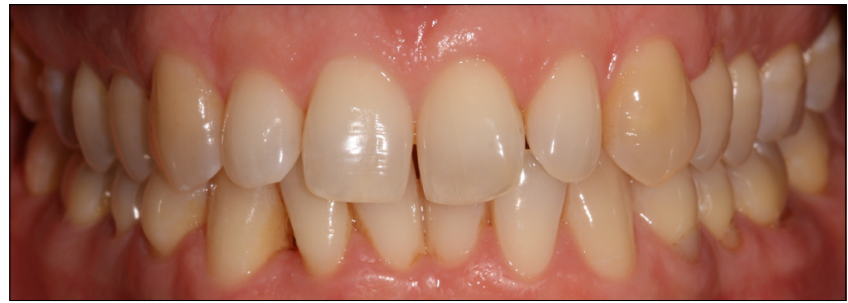

3. kép: Baleset előtti állapot

is a lehető legkevesebb egészséges foganyag feláldozása mellett. A gyógyulási periódust követően az implantátumokra felcsavarozható cirkónium-dioxid vázas porcelánleplezésű koronák készítését terveztük. Rendelkeztünk a balesetet megelőzően készült fogfotóval is, amely segítségünkre volt a végleges fogforma megtervezésében (3. kép)

\section{Eredmény}

A mútétet megelőzően a páciens szájhigiénés szaktanácsadáson vett részt rendelőnkben, amit EMS Airflow (Svájc) készülékkel végzett irányított biofilm-terápia (Guided Biofilm Therapy) végzése követte [9]. Az első két implantátum az 12 és 22 fogak helyére került, mivel ezek okoztak páciensünk számára a leginkább diszkomfortot. A mútétet lokális anesztéziában végeztük (2 ml $40 \mathrm{mg} / \mathrm{ml}$ artikain-hidroklorid, 0,012 mg/ml epinefrinhidroklorid, Ultracain DS Forte, Sanofi, Franciaország). A behelyezett implantátumok a 12 helyén: NobelActive TiUltra 3,5 × $13 \mathrm{~mm}$ (Nobel Biocare, Svédország), a 22 helyén: NobelActive TiUltra 3,5 × $15 \mathrm{~mm}$ (Nobel Biocare, Svédország). Az implantálást socket shield technikával végeztük el, a kezelési tervben leírtak szerint (4-5. kép). A rés kitöltésére Creos bovine bone mineral matrix, 0,2-1,0 mm (Nobel Biocare, Svédország) típusú csontpótlóanyagot használtunk. Az implantátumok primer stabilitása mindkét esetben $23 \mathrm{Ncm}$ volt, ami nem érte el az azonnali terhelés határértékét (32 Ncm) [1], ezért nem terhelhettük azokat ideiglenes koronákkal. Az eredeti nyálkahártya-kontúr lefutását azonban egyéni formára alakított zárósapkákkal megtartottuk. A foghiányokat a szomszédos fogakhoz rögzített ideiglenes koronákkal (Structur 3, vOCO GmbH, Németország) láttuk el. A beavatkozást követően 7 napos 1000 mg-os amoxicillin + klavulánsav terápiát rendeltünk el (Curam Duo, Sandoz, Svájc), napi $2 \times 1$ dózisban. Aznap a mútéti terület időszakos jegelését javasoltuk. A 11-es fog azonnali implantálását egy hónappal későbbre halasztottuk az interdentális csont és a papillák megőrzése céljából. A gyökér elhelyezkedésének anatómiai adottságai és a nehezített gyökércsúcs-eltávolítás miatt a mútétet feltárással kiegészített socket shield technikával végeztük el [8] (6. kép). A 11-es helyére NobelParalell Conical Connection TiUltra 4,3 × $13 \mathrm{~mm}$ (Nobel Biocare, Svédország) típusú implantátum került. A vestibulumban 


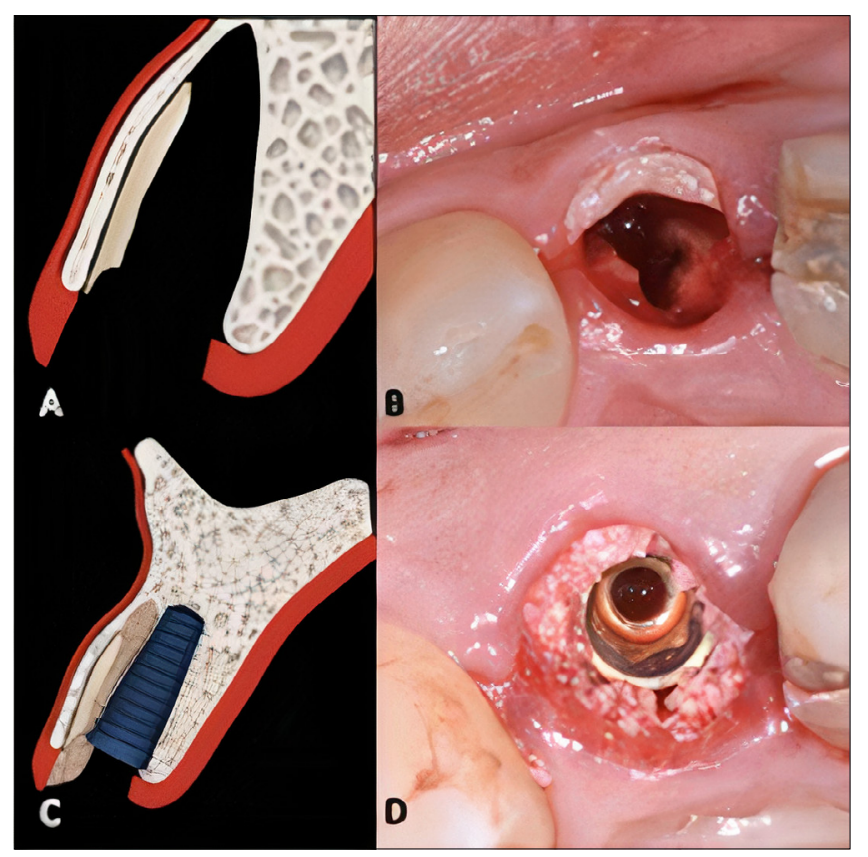

4. kép: A [4]: A megtartandó buccalis gyökérrészlet rajza, $B$ : A buccalis gyökérrészlet még paragingiválisan fut a végső forma kialakítása előtti állapotban,

$C[4]-D$ : a behelyezett implantátum sematikus rajza és klinikai képe

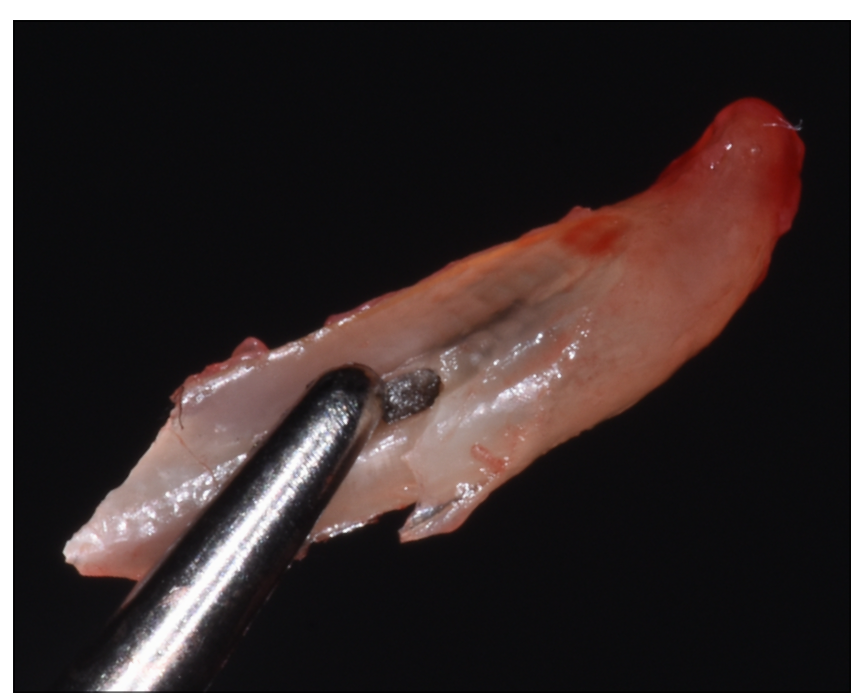

5. kép: A műtét során a gyökércsúcs eltávolításra került

képzett sebszélek egyesítésére 5/0-s monofil felszívódó varróanyagot (Monolac, Vitrex, Dánia) használtunk. Ebben az esetben a primer stabilitás $42 \mathrm{Ncm}$ volt, így ezt a foghiányt ideiglenes implantátumfejen (Temporary Snap Abutment Engaging CC $3 \mathrm{~mm}$, Nobel Biocare, Svédország) elhorgonyzott kompozit (Estelite Sigma Quick, Tokuyama Dental Corporation, Japán) koronával láttuk el. A felépülési időszak a páciens számára teljesen panaszmentes volt mindkét sebészi beavatkozás után, gyógyszeres fájdalomcsillapításra egyik esetben sem volt szüksége. Az egyhetes kontroll során klinikailag mindent rendben találtunk.

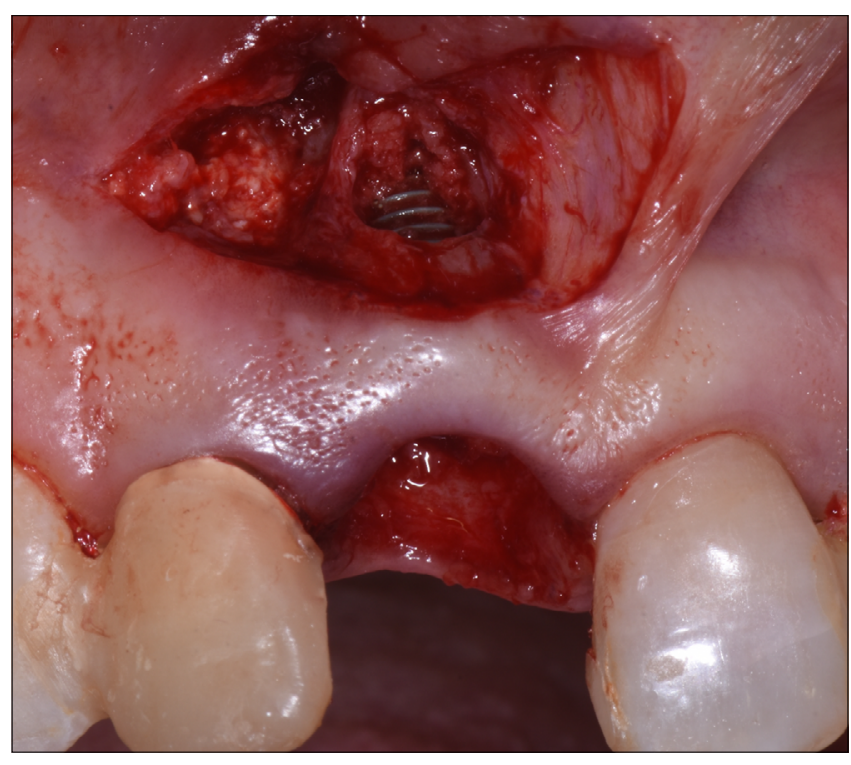

6. kép: 11-es foghiány implantálása feltárásból végzett socket shield technikával

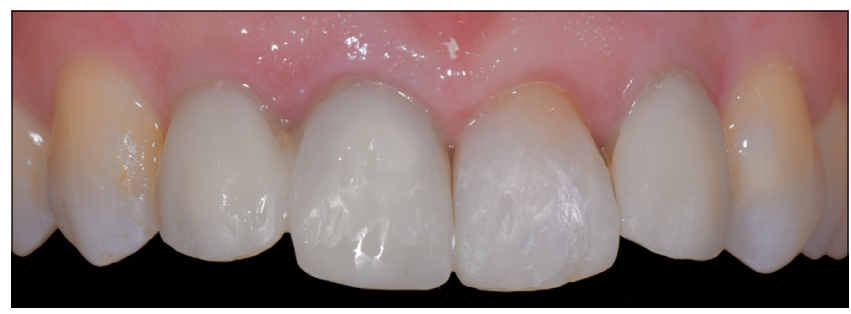

7. kép: Implantátumokon elhorgonyzott ideiglenes koronák

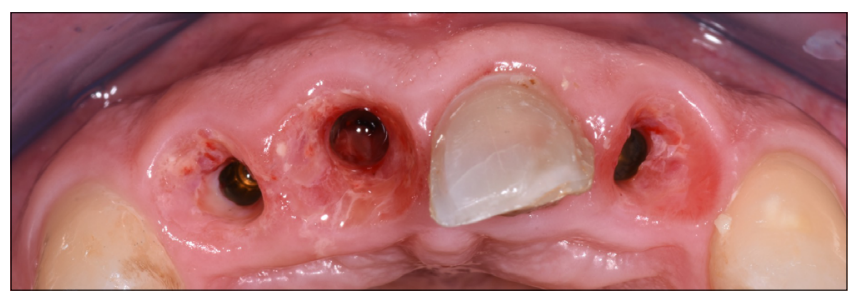

8. kép: A gingiva lefutása occlusalis nézetből a lenyomatvétel napján

A három hónapos gyógyulási periódust követően a 12-es és 22-es helyére került implantátumokat is felcsavarozott ideiglenes koronákkal (Temporary Snap Abutment Engaging CC $3 \mathrm{~mm}$, Nobel Biocare, Svédország) láttuk el (7. kép). Az implantátumok kontrollröntgenes ellenőrzését javasoltuk, de ekkorra páciensünk várandóssága első trimeszterében járt, és erre hivatkozva a röntgen készítését visszautasította. Az implantátumokat a fizikális vizsgálat stabilnak mutatta, a gyógyulási időszak panaszmentes volt. Az ideiglenes koronákat alkalmanként kompozittal tovább alakítottuk, hogy az íny kontúrja megfelelő lefutást érjen el a lenyomatvétel elött. A gingiva occlusalis nézetből is megtartotta korábbi lefutását (8. kép) 
A lenyomatvétel napján a rotált és elszíneződött bal fenti egyes fogat héjnak előkészítettük, a vállat a nyálkahártya kontúrjának megfelelően paragingiválisan vezettük. A kontaktpontokon a preparáció határa nem fordult át, a héj incisalis lezására pedig butt joint technikával történt, vagyis az éli részből $2 \mathrm{~mm}$-t vettünk el, ami egyben a héj palatinális lezárását is jelentette $[3,5]$ (9. kép). A sulcusba 000-ás Ultrapak retrakciós fonalat (Ultradent, Jordánia) vittünk be egy rétegben a lenyomat pontosságának növelése érdekében. Az ideiglenes koronákat előre elkészített, begipszelt technikai analógokba csavartuk, majd átlátszó szilikon lenyomatanyagot fecskendeztünk köré. Ezt követően a korona helyére helyeztük a lenyomati elemeket (Impression Coping Open Tray CC, Nobel Biocare, Svédország) majd hígan folyó flow kompozittal (Gradia Direct Flo, GC, USA) „rámásoltuk” az emergencia profilnak megfelelő területeket a lenyomati fejre (10. kép). Az egyéni fejes, implantátumszintű, nyitott kanalas lenyomatot két fázissal ISO „0” típusú alap és hígan folyó szilikonnal (Honigum Putty soft fast, DMG Chem.-Pharm. Fabrik GmbH, Németország) vettük két időben (11-12. kép). Páciensünknél nem álltak fenn a temporomandibularis ízületet érintő elváltozások, a baleset az eredeti harapási viszonyokat nem változtatta meg, így harapását szilikon harapási anyaggal (ExaBite II NDS, GC, USA) rögzítettük a két támasztózónában. Ezzel egy időben arcíves regisztráció is történt, a mintákat ARCUSevo arcív (KaVo, Németország) segítségével gipszeltük be Protar Evo VII (KaVo, Németország) artikulátorba. A készülő felépítményeket felcsavarozhatóra terveztük, mivel a roncsolás nélkül oldható kapcsolatnak számos előnye van a cementezett koronákkal szemben [11]. Az implantátumok dőlési szöge egyenes csavaros protetikai fejjel a buccalis oldalra vezette volna a csavarbemenetet, ami kedvezőtlen lenne esztétikai szempontból. Páciensünknek ferde csavarbemenetű titán közti elemeket (Metal adapter for Zirconia Abutment CC, Omnigrip Clinical Screw CC, Nobel Biocare, Svédország) választottunk - amikkel akár 25 fokos szögkorrekció is elérhető mind a három implantátum esetében. Ennek segítségével a csavarbemenet a felépítmény palatinális oldalára esett, így lehetőségünk volt felcsavarozható koronákat készíteni.

Mivel a héjhoz előkészített fog szomszédjai cirkóniumdioxid vázzal és ráégetett porcelánleplezéssel készülnek, a fogtechnikustól kértünk egy ugyanígy készített héjat és - a tartósabb rögzítés reményében - egy préskerámia-változatot is (13. kép). Az általunk választott fogszín A2, amit természetes fényben a kezelés megkezdése előtt határoztunk meg Ivoclar Vivadent A-D Shade Guide fogszínkulccsal (Ivoclar Vivadent GmbH, Lichtenstein). A héjhoz preparált fog csonkszíne ND2 volt az Ivoclar Vivadent Natural Die Material csonkszínkulcson (Ivoclar Vivadent GmbH, Lichtenstein). A 11-es és 12-es fog eredetileg összetérőbb volt és $V$ alakú diasthemát formázott. Ez a rés enyhe pöszeséget okozott a páciens elmondása szerint, így a végleges pótlásnál nem

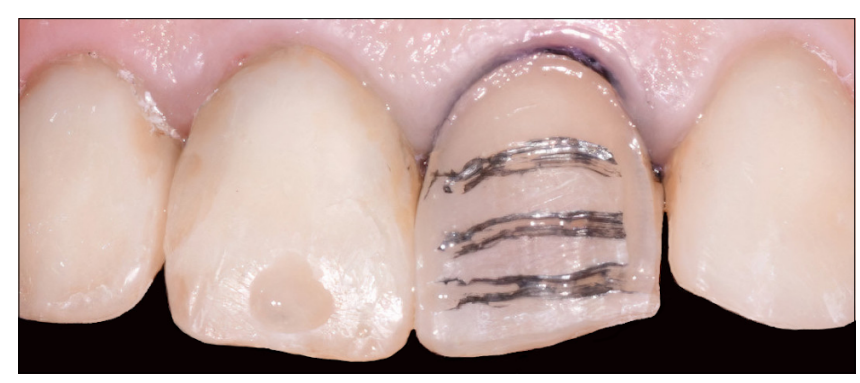

9. kép: 21-es fog preparálás közben

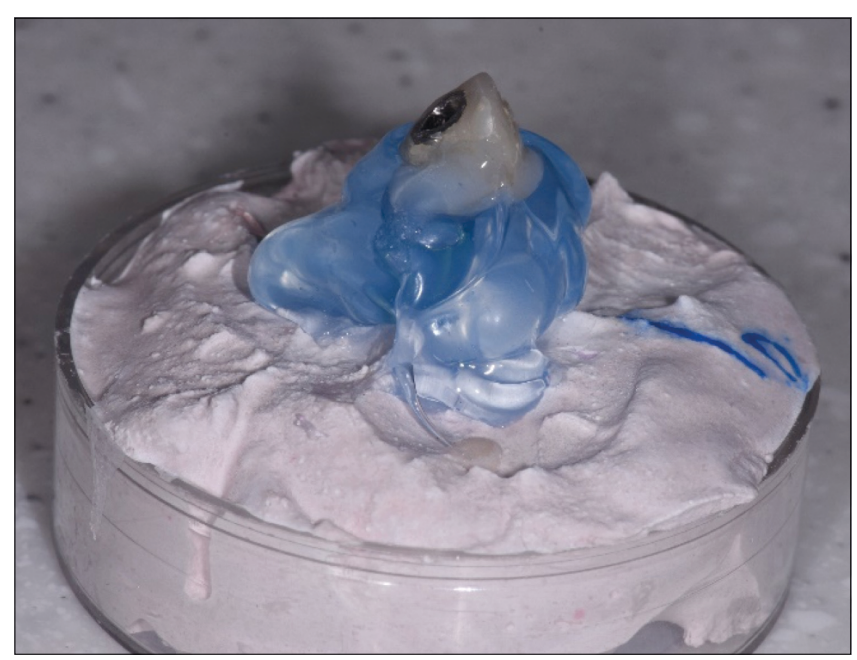

10. kép: Az ideiglenes korona gingiva alatti részletének átmásolása a lenyomati fejre

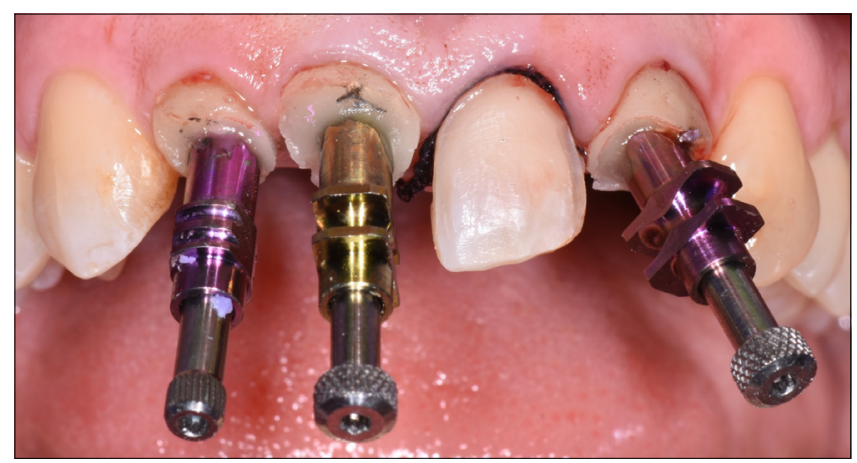

11. kép: Egyéni lenyomati fejek szájban, a preparált fog is készen áll a lenyomatvételre

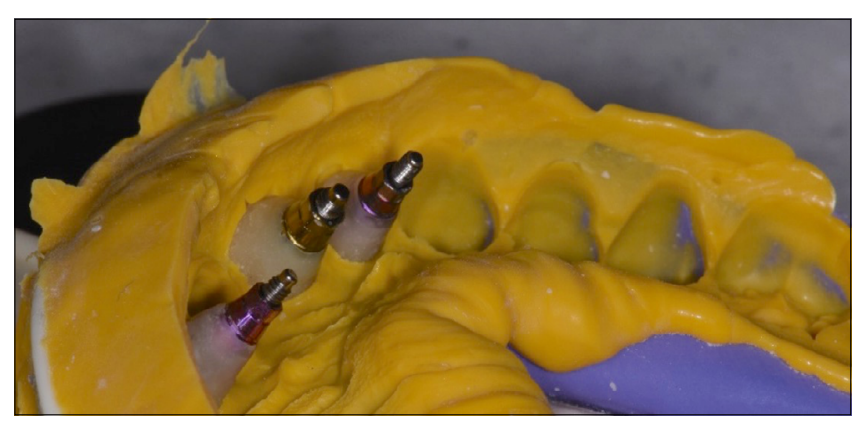

12. kép: Egyéni lenyomati fejek a lenyomatban 
törekedtünk az eredeti állapot teljes megmintázására (3. kép). A préskerámia-héj rögzítéséhez használt Calibra (Dentsply Sirona, USA) self-adhezív ragasztóanyag megfelelő színárnyalatú try-in pasztájával bepróbáltuk a kész héjat, és mivel esztétikailag nem maradt el a cirkónium-dioxid vázas héjhoz képest, így a pácienssel megbeszélve ezt választottuk véglegesnek. A beragasztást kofferdam izolálásban végeztük. $\mathrm{A}$ felesleges ragasztóanyag eltávolítása után átadásra kerültek az implantátumra felcsavarozható kész koronák is (14. kép). A pácienst kéthetes és három hónapos kontrollra is viszszarendeltük, ahol újbóli szájhigiénés kontrollt végeztünk (15. kép). A várandósságot követően elkészítettük a kontroll CBCT felvételt, amivel igazolni tudtuk, hogy az eljárásunk nemcsak klinikailag, hanem radiológiailag is kedvező végeredményt mutatott. A periimplantaris csontszövetet épnek találtuk, a buccalis csontfal pedig nem mutatott negatív csontremodellinget a baleset napján készült CBCT felvételhez képest. (16. kép)

\section{Megbeszélés}

A balesetben sérült fogak helyreállitása időigényes feladat volt, mivel a gyógyulási idők betartása elengedhetetlen az egyes beavatkozásokat követően. Az implantátumok behelyezését követően a páciens komfortérzete nagyban fokozódott, mivel az ideiglenes koronák ezután még erősebben rögzülhettek az átmeneti időszakban. Az azonnali implantáció és a socket shield technika alkalmazása segítségével meg tudtuk őrizni a csontszövet és a nyálkahártyakontúr eredeti lefutását. A nagyobb trauma ellenére a 21-es fog végig megtartotta vitalitását. Az időben eltolt beavatkozásoknak köszönhetően az interdentális papillák nem sérültek. A kontroll CBCT-felvétel igazolta az általunk választott eljárás radiológiai sikerességét. $A$ fogpótlások fehéresztétikája nem marad el a baleset előtti állapottól, köszönhetően a fémmentes eljárással készült fogpótlásoknak. Esetismertetésünkben a megfelelő sebészi és protetikai terápiákat együttesen alkalmazva sikeresnek mondható a funkció és az esztétika helyreállítása is, páciensünk nagyon elégedett volt a végeredménnyel.

\section{Irodalom}

1. AL-SAWAI A, LABIB H: Success of immediate loading implants compared to conventionally-loaded implants: a literature review. $J$ of Investig Clin Dent 2015; 7 (3), 217-224.

https://doi.org/10.1111/jicd.12152

2. ARAuJo MG, LINDHE J: Dimensional ridge alterations following tooth extraction. An experimental study in the dog. $J$ Clin Periodontol 2005; 32: 212-218. https://doi.org/10.1111/j.1600-051X.2005.00642.x

3. Chai S, Bennani V, AarTS JM, Lyons K: Incisal preparation design for ceramic veneers. J Am Dent Assoc 2018; 149 (1), 25-37. https://doi.org/10.1016/j.adaj.2017.08.031

4. Gluckman H, Salama M, Du Toit J: A retrospective evaluation of 128 socket-shield cases in the esthetic zone and posterior sites:

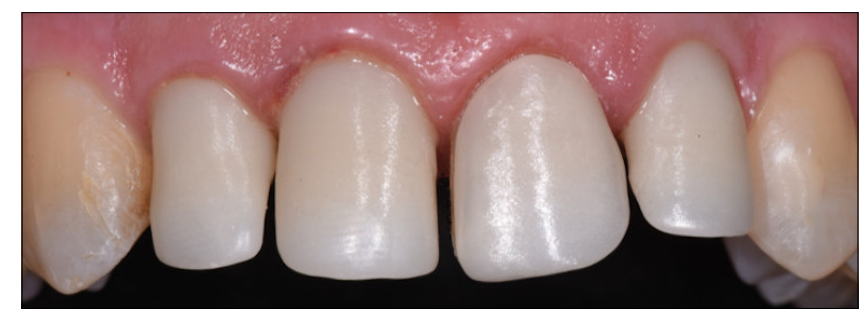

13. kép: Cirkónium-dioxid vázak próbája

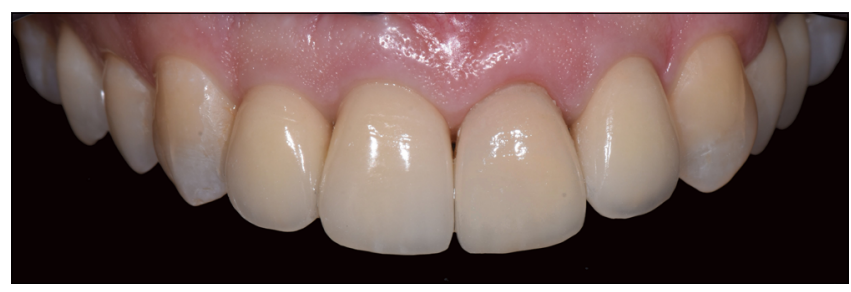

14. kép: Kész munka

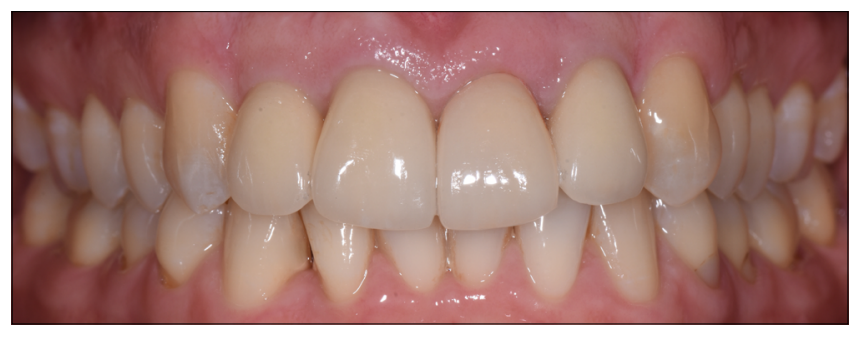

15. kép: 2 hetes kontroll

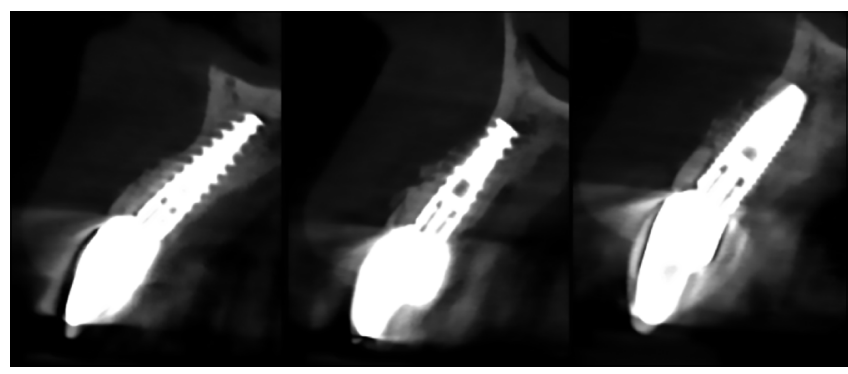

16. kép: Kontroll СBCT-felvétel

Partial extraction therapy with up to 4 years follow-up. Clin Implant Dent Relat Res 2017; 20 (2), 122-129. https://doi.org/10.1111/cid.12554

5. GüREL G: Porcelain Laminate Veneers: Minimal Tooth Preparation by Design. Dent Clin N Am 51 2007; 51, 419-443. https://doi.org/10.1016/j.cden.2007.03.007

6. Hürzeler M, Zuhr O, Schupbach P, Rebele SF, Emmanouilidis N, FICKL SJ: The socket-shield technique: a proof-of-principle report. Clin Periodontol 2010 Sep; 37 (9): 855-862. https://doi.org/10.1111/j.1600-051X.2010.01595.x

7. Kan J, Roe P, Rungcharassaeng K, Patel R, Waki T, Lozada J, Zimmerman G: Classification of Sagittal Root Position in Relation to the Anterior Maxillary Osseous Housing for Immediate Implant Placement: A Cone Beam Computed Tomography Study. Int J Oral Maxillofac Implants 2011 Jul-Aug; 26 (4): 873-876. 
8. Roe P, Kan JYK, Rungcharassaeng K: Residual root preparation for socket-shield procedures: a facial window approach. Int J Esthet Dent 2017; 12 (3): 324-335.

9. VadócZ R, CsÁszÁR Z, NAGY K, Kivovics P: Guided Biofilm Therapy. Magyar Fogorvos 2016; 5 238-241.

10. Weigl $P$, Strangio $A$ : The impact of immediately placed and restored single-tooth implants on hard and soft tissues in the anterior maxilla. Eur J Oral Implantol 2016; 9 Suppl 1: S89-106.

11. Wittneben JG, Joda T, Weber HP, Brägger U: Screw retained vs. cement retained implant-supported fixed dental prosthesis. Periodontol 2000 2017; Feb. 73 (1): 141-151. https://doi.org/10.1111/prd.12168
12. Zaleckiene V, Peciuliene V, Brukiene V, Drukteinis $\mathrm{S}$ : Traumatic dental injuries: etiology, prevalence and possible outcomes. Stomatologija 2014; 16: 7-14.

13. Zuhr O, Staehler P, Hürzeler M: Complication Management of a Socket Shield Case After 6 Years of Function. Int J Periodontics Restorative Dent 2020; 40 (3), 409-415. https://doi.org/10.11607/prd.4648

14. https://www.nobelbiocare.com/blog/tag/angulated-screw-channel/ (2020.11.20.)

\section{Complex rehabilitation of traumatized permanent teeth in the aesthetic zone}

\section{Case study}

The aim of this case study is to present our treatment method for the restoration of traumatic lesions of teeth following a bicycle accident. Four upper incisors were injured; thus, special consideration was required in timing of the treatment sequence. The prognosis for teeth \#11, 12, and 22 was discouraging; furthermore, due to accident, tooth \#21 suffered additional rotation and discolouration. In order to preserve the original form and the aesthetics of the mucosa as well as the height of the interdental papillae, immediate implant placement in combination with the socket shield technique were chosen. To accommodate the timing and the state-of-art realisation of the surgical procedure, placements of the three implants were divided into two separate sessions. Whilst immediate replacement of tooth \#11 was possible, the placement of the two other implants was only feasible after a healing period of three months. Temporary crowns were placed to preserve aesthetic mucosal margins and the emergence profiles prior to impression, which was taken using individualised custom impression copings. A pressable ceramic veneer was chosen to hide the discolouration of tooth 21 . The outcome shows suitable aesthetic, stable soft tissues, preserved emergence profiles, metal-free screw-retained implant crowns, and a veneer, all of which confirm the correct choice for the treatment modality.

Keywords: accident, socket shield technique, immediate implant placement, metal-free 